\title{
JAN PAWEE II A 1550. ROCZNICA SOBORU EFESKIEGO
}

Tego tematu temu Organizatorowi nie mogłem odmówić. Kiedy ćwierć wieku temu organizowałem „Sympozjum Efeskie” (Niepokalanów, 14-16 września 1981 roku), byłem świadomy, że dogmatyk winien pokłonić się patrologom z prośbą o współpracę. Ks. Stanisław Longosz, ówcześnie tylko „doktor”, nie dał się prosić. Został niezmiernie cennym współorganizatorem. Nad chrystologicznym i mariologicznym Efezem zaświeciły wielkie gwiazdy polskiej patrystyki: ks. dr Marek Starowieyski, ks. doc. Wacław Eborowicz, ks. dr Jerzy Woźniak, ks. dr Stanisław Longosz, prof. Claude Mondésert SJ z Lyonu, o. dr Andrzej Bober SJ i ks. dr hab. Wojciech Kania. Dzięki inicjatywie ks. S. Longosza nasze sympozjum wzbogacili także historycy sztuki ${ }^{1}$. Po 16 latach ukazały się materiały tamtego sympozjum pt. Maryja w tajemnicy Chrystusa ${ }^{2}$. Tamto doświadczenie przekonało o głębokiej sensowności interdyscyplinarnej współpracy teologów różnych dziedzin. Oprócz kilku innych swoich tekstów zamieściłem we wspomnianej publikacji komunikat pt. Jubileuszowe oceny Soboru Efeskiego: Pius XI (1931 r.) - Jan Pawet II (1981 r. $)^{3}$. Na jednej stroniczce omówiłem dokument, który dzisiaj, po 25 latach, wolno mi dokładniej omówić na wysokim spotkaniu polskich patrologów. Chodzi mi oczywiście o List Ojca Świętego Jana Pawła II do Episkopatu Kościoła Katolickiego na 1600 rocznicę I Soboru Konstantynopolitańskiego i na 1550 rocznicę Soboru Efeskiego z dnia 25 marca 1981 roku $^{4}$. Część poświęconą Soborowi Konstantynopolitańskiemu omówi ktoś inny, ode mnie zaś oczekuje się omówienia tych fragmentów, które odnoszą się do Soboru Efeskiego. Słowo Papieża otrzymało w nich następującą sekwencję logiczną:

${ }^{1}$ Szczegółowy program i sprawozdanie z tego sympozjum zob. S. Longosz, Sympozjum Efeskie, VoxP 1 (1981) z. 1, 65-68; A. Malinowski, Sympozjum Efeskie w Niepokalanowie, VoxP 2 (2982) z. 2, 60-79.

2 Praca zbiorowa pod redakcją C.S. Napiórkowskiego OFMConv i ks. S. Longosza, Niepokalanów 1997, Wydawnictwo Ojców Franciszkanów, ss. 350.

${ }^{3}$ Por. tamże, s. 100-103.

4 Jego tekst zob. AAS 73 (1981) 513-527, przekład polski OsRomPol 2 (1981) nr 3, 12-13, przedruk w: VoxP 1 (1981) z. 1, 5-20, lub w: Maryja w tajemnicy Chrystusa, s. 317-325. 
- chrystologiczne znaczenie Soboru Efeskiego,

- jego znaczenie dla soteriologii,

- doniosłość dla mariologii,

- eklezjologiczny kontekst nauki o Theotokos,

- udział Ducha Świętego w dziele wcielenia i zbawienia,

- funkcja wiary i posłuszeństwa Maryi,

- wnioski dla chrześcijan: radość z tych tajemnic i wdzięczność za nie oraz potrzeba budzenia wiary i służenia wierze, przypominanie roli Ducha Świętego w życiu Kościoła i Maryi.

Wydawać by się mogło, że o teologii Efezu nie da się już nic świeżego powiedzieć, a jednak można. Swoiste novum papieskiego ujęcia we wspomnianym Liście można zasadnie widzieć w postrzeganiu Efezu w kontekście Soborów - Konstantynopolitańskiego I i Watykańskiego II.

1. W kontekście Soboru Konstantynopolitańskiego I. Pomysł jednego Listu z okazji dwu soborów sprowokował do myślenia o Efezie w kontekście Konstantynopola. Tradycyjnie postrzegano nauczanie Efezu jako nauczanie o Maryi w kontekście nauczania o Chrystusie; mariologom przypominano, że Sobór Efeski to jednak głównie chrystologia, nie mariologia, a słowo o Matce Pana jako Theotokos służyło właściwej interpretacji misterium Słowa Wcielonego. Jan Paweł II przejmuje w Liście ten kierunek myślenia:

„Sobór Efeski miał przede wszystkim walor chrystologiczny, gdyż zdefiniował prawdę o istnieniu dwóch natur w Jezusie Chrystusie, Boskiej i ludzkiej, aby w ten sposób uściślić autentyczną naukę Kościoła, wyrażoną już przez Sobór w Nicei w roku 325, która jednak była zagrożona przez głoszenie różnych interpretacji prawdy wyjaśnionej na tym Soborze" 5 .

Jednak Papież nie poprzestaje na tym tradycyjnym myśleniu. Bogaci je interpretacją soteriologiczną:

\begin{abstract}
„W ścisłym związku z tymi orzeczeniami Sobór Efeski miał również znaczenie soteriologiczne, naświetlając, że - według znanego adagium «nie doznało uzdrowienia to, czego Chrystus nie przyjął» [...]. Był to jeden hymn owych starożytnych Ojców na cześć wcielenia Jednorodzonego Syna Bożego, w pełnej prawdzie dwóch natur w jednej osobie; był to hymn na cześć dzieła zbawienia dokonanego w świecie przez działanie Ducha Świętego"6.
\end{abstract}

Wzbogaca je także interpretacją pneumatologiczną, o której mówił dopiero co w pierwszej części Listu, poświęconej Soborowi Konstantynopolitańskiemu. Podkreśla, że zbawcze wcielenie, w których uczestniczyła i współdziałała Ma-

\footnotetext{
Epistola 3, VoxP z. 1, 8-9.

6 Tamże, s. 9.
} 
ryja, dokonało się „przez działanie Ducha Świętego” i „przez pełne blasku zstąpienie Ducha Świętego", że wówczas Maryja:

„stała się stworzeniem najściślej złączonym z dziełem zbawienia. Wcielenie dokonało się pod Jej sercem za sprawą Ducha Świętego. W Niej zabłysła jutrzenka nowej ludzkości, która z Chrystusem ukazała się na świecie, aby wypełnić pierwotny plan przymierza z Bogiem zerwany przez nieposłuszeństwo pierwszego człowieka. Et incarnatus est de Spiritu Sancto ex Maria Virgine"”.

Bogaci je również interpretacją ekumeniczną. Przypomina, że oba Sobory przynależą do wspólnego dziedzictwa wiary wszystkich chrześcijan ${ }^{8}$. Wyraża nadzieję, że przypomnienie obu Soborów:

„które były wyrazem wiary nauczanej i wyznawanej przez Kościół nie podzielony, przyczynią się do wzrostu wzajemnego zrozumienia z naszymi Umiłowanymi Braćmi na Wschodzie i na Zachodzie" 9 .

Przypomnienie i ożywienie tamtej wspólnej wiary, która trwa nawet po podziale, uważa za znakomicie służące przyspieszeniu drogi do zjednoczenia ${ }^{10}$.

Ubogaca je wreszcie wskazaniem na duchową płodność tych tajemnic także w naszych czasach. Również dzisiaj Misteria kontemplowane na tamtych Soborach mogą i powinny być dla nas źródłem radości, wdzięczności, ożywionej wiary i nowego dynamizmu duchowego ${ }^{11}$. Szczególnie biskupów, kapłanów i osoby zakonne zachęca, by obie rocznice postrzegali jako przypomnienie tajemnic bardzo ,dzisiejszych"12.

Poddając List Jana Pawła II uważnej lekturze, podjętej z myślą o teologicznej prezentacji, nie można pominąć stosunku Autora do kwestii Nestoriusza, który za św. Cyrylem Aleksandryjskim - z zasady był postrzegany jako czołowy heretyk, odrzucający Boże Macierzyństwo Maryi wraz z tytułem Theotokos. W 2. poł. $\mathrm{XX}$ wieku podjęto próbę bardziej obiektywnego spojrzenia na Nestoriusza ${ }^{13}$.

\footnotetext{
7 Tamże, s. 10.

${ }^{8}$ Por. tamże 4.

9 Tamże 5, VoxP z. 1, s. 12.

${ }_{10}$ Por. tamże.
}

${ }^{11}$ Por. tamże 4, VoxP z. 1, s. 11: „Wszystko to jest dla nas źródłem przeogromnej radości, źródłem wdzięczności za światło tej wiary, poprzez którą uczestniczymy w niezgłębionych tajemnicach Bożych, czyniąc je treścią życia naszych dusz, rozszerzając w nich horyzonty widzenia naszej duchowej godności i naszych ludzkich przeznaczeń. I dlatego też te wielkie rocznice nie mogą dla nas pozostać tylko wspomnieniem z odległej przeszłości. Muszą odżyć w wierze Kościoła. Muszą odezwać się nowym echem w jego duchowości, muszą znaleźć nawet wewnętrzny wyraz swej stale żywej aktualności dla całej wspólnoty wierzących".

12 Por. tamże 5.

13 Por. A. Grillmeier, Christ in Christian Tradition, London $1975^{2}$, 472: „Nestoriusz - uchodzący za czołowego herezjarchę chrześcijaństwa - od kilkudziesięciu lat stał się przedmiotem nowych studiów. Stwierdzamy niejaki proces rehabilitacji. Dokonuje się go na dwu drogach: 
Hiszpańskie wydanie tekstów Nestoriusza ${ }^{14}$, ułatwiające dostęp do samego źródła, pozwala stwierdzić, że niemal powszechnie wypacza się Nestoriuszową interpretację tytułu Christotokos. Owszem, Nestoriusz uważał, że tytuł Theotokos, nie jest najszczęśliwszy, gdyż jest jednostronny i sugeruje, że w Maryi Bóg wziął początek, iż poczęła Bóstwo. Podobnie nie najszczęśliwszy ze względu na jednostronność jest tytuł Antropotokos, ponieważ sugeruje, że Chrystus był tylko człowiekiem. Kiedy natomiast mówimy o Christotokos, wyrażamy najpełniej prawdę o Chrystusie jako Chrystusie, który był i Bogiem, i człowiekiem. W tytule Christotokos zawiera się zarówno tytuł Theotokos jak Antropotokos ${ }^{15}$.

Czy w Liście Jana Pawła II słyszymy echa nowej dyskusji wokół Nestoriusza? Otóż Jan Paweł II nie zajmuje stanowiska wobec sprawy Nestoriusza. Nie przypisuje mu ani odrzucenia Theotokos, ani interpretowania Christotokos $\mathrm{z}$ sensie Antropotokos. Wspomina tego patriarchę, ale tylko jeden raz (wspominając listy św. Cyryla do Nestoriusza) i to bez ustosunkowywania się do jego nauki o Theotokos ${ }^{16}$. Błędne nauczanie o Bożym Macierzyństwie wiąże natomiast z nestorianizmem, chociaż nie obciąża go wyraźnie główną odpowiedzialnością ${ }^{17}$.

2. W kontekście Soboru Watykańskiego II. Soborowe wydarzenie i przesłanie sprzed 1550 lat Jan Paweł II odczytuje także w światłach Soboru Watykańskiego II: uznaje ich aktualność dla Kościoła naszego życia ${ }^{18}$. Jeśli światła

1. na drodze historyczno-psychologicznej zwraca się uwagę na różne szczegóły, wydarzenia historyczne, które decydowały o radykalizmie przeciwników Nestoriusza oraz na nietakty popełniane przez Cyryla i papieża Celestyna;

2. na drodze hermeneutyczno-teologicznej: a) współczesne uwrażliwienie językowe jako owoc hermeneutyki pozwoliło nam dostrzec nieporozumienia terminologiczne i brak precyzji pod piórem św. Cyryla Aleksandryjskiego; b) nadto usiłuje się na nowo odczytywać Nestoriusza, bez uprzedzeń i założeń, iż tam musi być herezja. Mówi się, że np. synod rzymski zwołany w sprawie Nestoriusza, niewłaściwie potraktował jego sprawę; zob. G. Söll, Mariologie HDG III 4, Freiburg i. B. 1978,93 .

14 Por. S. Alvarez Campos (ed.), Corpus Marianum Patristicum, IV/1, Burgos 1976, nr 29252982, s. 7-34.

15 Por. S.C. Napiórkowski, Czy można zrehabilitować Nestoriusza?, ,Summarium” 1980, nr 9(29), 131-134, lub w: tenże, Matka mojego Pana (problemy-poszukiwania-perspektywy), Opole $1988,129-132$.

${ }^{16}$ Por. Epistola 3, VoxP z. 1, s. 9: ,,[...] prawda dotycząca Najświętszej Dziewicy, powołanej do jedynej i niepowtarzalnej godności Matki Boga, Theotokos, jak to jasno zostało uwydatnione głównie w listach Cyryla do Nestoriusza”.

${ }^{17}$ Por. tamże 3, VoxP z. 1, s. 8-9: „,Sobór Efeski miał przede wszystkim walor chrystologiczny, gdyż zdefiniował prawdę o istnieniu dwóch natur w Jezusie Chrystusie, Boskiej i ludzkiej, aby w ten sposób uściślić autentyczną naukę Kościoła, wyrażoną już przez Sobór w Nicei w roku 325, która jednak była zagrożona przez głoszenie różnych interpretacji prawdy wyjaśnionej na tym Soborze, zwłaszcza zaś przez głoszenie różnych sformułowań używanych w nauczaniu nestoriańskim”.

${ }^{18}$ Por. tamże 6, VoxP z. 1, s. 12-13: ,Jest zatem moim pragnieniem, aby te wydarzenia zostały przeżyte $\mathrm{w}$ ich głębokim kontekście eklezjologicznym. Powinniśmy bowiem nie tylko przypominać 
Soboru Konstantynopolitańskiego I pozwoliły pogłębić nauczanie Efezu perspektywą pneumatologiczną, soteriologiczną, ekumeniczną i egzystencjalnoduchową, to światła Soboru Watykańskiego II wniosły perspektywę eklezjologiczną. Przecież odnowa eklezjologii dokonana na Vaticanum II dokonała się w olbrzymiej mierze dzięki otwarciu jej na Ducha Świętego. Według Soboru Duch Swięty ustawicznie uświęca, daje życie, mieszka w Kościele i w sercach wiernych, prowadzi Kościół do pełni prawdy, jednoczy we wspólnocie i posługiwaniach, bogaci w różne dary tak charyzmatyczne, jak hierarchiczne, kieruje, zdobi, utrzymuje Kościół w ciągłej młodości, odnawia go i prowadzi do pełnego zjednoczenia z Oblubieńcem ${ }^{19}$.

Sobór Watykański II w swoim słowie o Maryi w tajemnicy Chrystusa i Kościoła podkreślił macierzyństwo Maryi w Kościele ${ }^{20}$. Jan Paweł II wykorzystał to, by uwspółcześnić (aggiornamento) naukę efeską sprzed 1550. laty. Przypomniał, że Jej macierzyństwo:

„nie tylko jest źródłem i podstawą całej wyjątkowej świętości Maryi i Jej najszczególniejszego udziału w całej ekonomii zbawienia, ale ustala ponadto trwały związek macierzyński Maryi z Kościołem, mający swą podstawę w samym fakcie, że została Ona przez Trójcę Przenajświętszą wybrana na Matkę Chrystusa, który jest «Głową Ciała-Kościoła»"21.

Papież rozwija tę myśl przywołując tekst Vaticanum $\mathrm{II}^{22}$. Wyraźniej niż perspektywę eklezjologiczną Papież podkreśla perspektywę pneumatologiczną, nawiązuje jednak przy tym nie do Soboru w Efezie, a do Soboru w Konstantynopolu.

te wielkie rocznice jako jedynie fakty z przeszłości - ale ożywić je również naszą współczesnością i związać głęboko z życiem i zadaniami Kościoła naszej epoki, tak jak zostały one wyrażone w całym nauczaniu Soboru naszych czasów: Vaticanum II. Jakże głęboko żyją w tym nauczaniu prawdy wyjaśnione na tamtych Soborach, a równocześnie jakże te właśnie prawdy przeniknęły treść centralnego dla Vaticanum II nauczania o Kościele! Jakże są dla tego nauczania istotne i konstytutywne, a równocześnie jak bardzo te podstawowe i centralne prawdy naszego Credo żyją niejako nowym życiem i świecą nowym światłem w całości nauczania Vaticanum II!’.

${ }^{19}$ Por. Lumen gentium 4.

20 Por. tamże 58-59.

21 Epistola 8, VoxP z. 1, s. 15.

22 Por. tamże, s. 16: „Sobór Watykański II szczęśliwie syntetyzuje dalej ten nierozerwalny związek Maryi z Chrystusem i z Kościołem: «A kiedy podobało się Bogu uroczyście objawić tajemnice zbawienia ludzkiego nie wcześniej, aż ześle obiecanego przez Chrystusa Ducha, widzimy Apostołów przed dniem Zielonych Świąt, trwających 'jednomyślnie na modlitwie wraz z niewiastami, Maryją, Matką Jezusa, i braćmi Jego' (Dz 1, 14), także Maryję błagającą w modlitwach o dar Ducha, który podczas zwiastowania już Ją był zacienił» (Lumen gentium 59). W sformułowaniu tym tekst soborowy zestawia z sobą dwa momenty, w których Macierzyństwo Maryi najściślej związane jest z dziełem Ducha Przenajświętszego: najpierw moment Wcielenia, z kolei zaś moment narodzin Kościoła w Wieczerniku jerozolimskim”. 


\title{
GIOVANNI PAOLO II E IL $1550^{\circ}$ ANNIVERSARIO DEL CONCILIO DI EFESO
}

\author{
(Riassunto)
}

Si potrebbe pensare che sulla teologia dell'Efeso non sia più possibile dire qualcosa di nuovo, eppure è possibile. E' giusto affermare infatti che la Lettera del Santo Padre Giovanni Paolo II all'Episcopato della Chiesa Cattolica per il 1600 anniversario del Primo Concilio di Costantinopoli I e per il 1550 anniversario del Concilio di Efeso (25 III 1981) offre una visione in qualche modo rinnovata dell'Efeso riconsiderandolo nell'ottica del Concilio di Costantinopoli e del Vaticano II.

1. Nel contesto del Concilio di Costantinopoli: alla tradizionale interpretazione cristologica e mariologica dell'Efeso, Giovanni Paolo II aggiunge l'interpretazione soteriologica (l'Efeso cantò ,un'inno all'onore dell'opera di salvezza compiuta nel mondo attraverso l'azione dello Spirito Santo"), quella pneumatologica (l'incarnazione si fece per l'azione dello Spirito Santo ) e quella ecumenica (i due Concili appartengono alla stessa eredità della fede ). Egli sottolinea ugualmente la permanenza della fertilità spirituale di quei misteri. Il Papa non si esprime sul problema di Nestorio ; non lo accusa di eresia ; il nestorianismo e l'insegnamento sbagliato sulla maternità divina rimangono legati, ma il movimento non ne è ritenuto il principale responsabile.

2. Nel contesto del Vaticano II: rifenrendosi all'insegnamento del Vaticano II relativo alla presenza della Vergine Maria nel Mistero della Chiesa, Giovanni Paolo II dà rilievo alla prospettiva ecclesiologica dell'Efeso: lo Spirito Santo santifica in continuazione la Chiesa, le dà la vita, abita nei cuori dei fedeli, conduce la Chiesa alla pienezza della verità, la unifica nelle sue communità e attività pastorali, la dirige, la decora, la mantiene sempre giovane, la rinnova e la conduce all'unione totale con il Cristo. Maria Santissima, unita allo Spirito Santo, sta realizzando la sua maternità nella Chiesa. 